\title{
Oral Insulin Treatment Suppresses Virus-induced Antigen-specific Destruction of $\beta$ Cells and Prevents Autoimmune Diabetes in Transgenic Mice
}

\author{
Matthias G. von Herrath, ${ }^{*}$ Thomas Dyrberg, ${ }^{\ddagger}$ and Michael B.A. Oldstone ${ }^{\star}$ \\ *Department of Neuropharmacology, Division of Virology, The Scripps Research Institute, La Jolla, California 92037; \\ and ${ }^{\ddagger}$ Novo Nordisk, Bagsvaerd, Denmark
}

\begin{abstract}
Oral administration of self-antigens has been proposed as a therapy to prevent and treat autoimmune diseases. Here we report that oral treatment with insulin prevents virus-induced insulin-dependent diabetes mellitus (IDDM) in a transgenic (tg) mouse model. Such mice express the viral nucleoprotein (NP) of lymphocytic choriomeningitis virus (LCMV) under control of the rat insulin promoter in their pancreatic $\beta$ cells and $<2 \%$ spontaneously develop diabetes. However, 2 mo after challenge with LCMV, IDDM occurs in $>95 \%$ of $\mathrm{tg}$ mice but not in controls. Oral treatment with $1 \mathrm{mg}$ of insulin twice per week for 2 mo starting either 1 wk before or $10 \mathrm{~d}$ after initiating LCMV infection prevents IDDM in $>50 \%$ of the tg mice (observation time $8 \mathrm{mo}$ ). Thus, insulin therapy is effective in preventing progression to overt IDDM in prediabetic tg mice with ongoing islet infiltration. Oral administration of insulin does not affect the generation of LCMV-NP-specific anti-self cytotoxic $T$ lymphocytes nor the infiltration of lymphocytes into the pancreas. However, less $\beta$ cells are destroyed in insulin-treated mice, upregulation of MHC class I and II molecules does not occur, and antiviral (self) cytotoxic $T$ lymphocytes are not found in the islets, events present in tg mice developing IDDM. The majority of lymphocytes in the islets of insulin-treated tg mice without IDDM produces IL-4, IL-10, and TGF- $\beta$. In contrast, lymphocytes from islets of tg mice developing IDDM mainly make $\gamma$-IFN. (J. Clin. Invest. 1996. 98:1324-1331.) Key words: oral tolerance $\bullet$ insulin-dependent diabetes mellitus - lymphocytic choriomeningitis virus - insulin • bystander suppression
\end{abstract}

\section{Introduction}

Insulin-dependent diabetes mellitus (IDDM), ${ }^{1}$ also known as type 1 diabetes or juvenile onset diabetes, results from destruc-

Address correspondence to Matthias G. von Herrath, Division of Virology, Department of Neuropharmacology, IMM6, The Scripps Research Institute, 10666 North Torrey Pines Road, La Jolla, CA 92037. Phone: 619-554-9602; FAX: 619-554-6705; E-mail: matthias@scripps.edu

Received for publication 7 February 1996 and accepted in revised form 18 July 1996.

1. Abbreviations used in this paper: APC, antigen-presenting cell; CTL, cytotoxic T lymphocyte(s); GAD, glutamic acid decarboxylase; IDDM, insulin-dependent diabetes mellitus; LCMV, lymphocytic choriomeningitis virus, ARMSTRONG (ARM) strain; NP, nucleoprotein; RIP, rat insulin promoter; TcR, $\mathrm{T}$ cell receptor; $\mathrm{tg}$, transgenic.

J. Clin. Invest.

(C) The American Society for Clinical Investigation, Inc. 0021-9738/96/09/1324/08 \$2.00

Volume 98, Number 6, September 1996, 1324-1331 tion of the insulin-producing $\beta$ cells located in the pancreatic islets of Langerhans (1-4). The disease is characterized by hyperglycemia, hypoinsulinemia, and mononuclear cell infiltration in the islets. Factors involved in the pathogenesis include MHC genes, aberrant immune responses, and perhaps viruses (5-9). Injury to $\beta$ cells usually occurs over a prolonged period of time, but the precise self-antigens involved in the initiation or continuance of the autoimmune process or the effector mechanism(s) remain largely unknown. Currently no cure or effective prevention is available (10).

Antigen-specific immunotherapy using self-antigens or peptides has been proposed as a treatment for autoimmune diseases (11-14). Further, oral administration of self-antigens to induce "oral tolerance" $(15,16)$ has been used as a therapy for several autoimmune disorders $(14,15,17,18)$. Depending on the dose and composition of the orally administered antigen, such treatment has been proposed to be effective via two different pathways. High doses of antigen may cause peripheral deletion, anergy, or exhaustion of inflammatory autoreactive cells $(17,19,20)$. The result is tolerization of anti-self-specific $\mathrm{T}$ cells, rendering them unable to cause disease. Intermediate doses of antigen may lead to antigen-driven bystander suppression presumably through the release of immunoregulatory cytokines such as TGF- $\beta$ and IL-4 (21-26). This approach allows treatment of an organ-specific disease when the initiating autoantigen is not known.

To date, oral tolerance studies to treat IDDM have been performed in animal models, where the self-antigens involved in the initial phase of autoimmune disease are not known. In this report we analyze the effect of oral insulin therapy in a well-characterized transgenic ( $\mathrm{tg}$ ) mouse model in which the self-antigen involved in the autoimmune disease is known (8, 9,27 ). This enabled us to dissect out the initiating (triggering) anti-self (viral) immune response from the immunosuppressive bystander effect induced by oral tolerization. In our model the initiating self-antigen is a viral protein expressed as a transgene in the $\beta$ cells of the islets of Langerhans by use of the rat insulin promoter (RIP) (8). IDDM develops in all lines after initiation by viral (LCMV) infection and the T cells and cytokines involved in causing disease are known. Briefly, the $\mathrm{tg}$ mouse lines express the nucleoprotein (NP) or glycoprotein (GP) of LCMV. Peripheral ignorance to the viral (self) transgene is broken by challenge with LCMV, and IDDM develops in $>95 \%$ of such mice $(8,9)$. When the viral transgene is expressed only in the $\beta$ cells, a rapid-onset IDDM occurs at 10-14 d after infection and antiviral (self) $\mathrm{CD}^{+} \mathrm{T}$ cells are required $(8$, $9,27)$. However, if the transgene is expressed in both the $\beta$ cells and the thymus, a slow-onset IDDM occurs that takes 1-6 mo to develop depending on the host's MHC haplotype $(8,9$, 28). In the slow-onset IDDM model, high affinity anti-self (viral) cytotoxic $\mathrm{T}$ lymphocytes (CTL) are deleted and CTL found in the periphery are of low affinity $(9,29)$.

Using the slow-onset model of virus-induced IDDM, we note that oral therapy with insulin before or $10 \mathrm{~d}$ after the on- 
set of viral infection prevents IDDM in $>50 \%$ of the tg mice. The generation of the anti-self (viral) CTL response is not inhibited and $\mathrm{T}$ cell infiltration of islets occurs in such protected $\operatorname{tg}$ mice. However, the degree of infiltration is reduced and fewer $\beta$ cells are destroyed. Further, in the islets of these protected mice the number of lymphocytes producing IL-4, IL-10, and TGF- $\beta$ is significantly increased. This stands in contrast to observations made with both non-insulin-treated mice or insulin-treated mice that develop IDDM, where both groups show a greater degree of infiltration into the islets with destruction of most or all $\beta$ cells, a higher proportion of $\mathrm{T}$ lymphocytes making $\gamma$-IFN and fewer T cells producing IL-4, IL-10, and TGF- $\beta$.

\section{Methods}

\section{Transgenic lines and viral strains}

Transgenic lines. Generation and characterization of RIP-LCMV tg mice with rapid (8-14 d) or slow-onset (1-6 mo) IDDM after LCMV infection have been described (9). RIP-GP 34-20 (H-2 $\left.2^{b}\right)$ tg mice which express the viral GP only in the $\beta$ cells of the islets were used as a model for rapid-onset IDDM. For slow-onset IDDM, RIP-NP 25-3 $\left(\mathrm{H}-2^{\mathrm{d}}\right)$ tg mice were used. RIP-NP 25-3 mice express the viral NP in the pancreas and the thymus but not in any other tissues (9).

Virus. Virus stocks consisted of LCMV ARM (clone 53b) and vaccinia virus recombinants that express the LCMV-GP aa1-398 (vv/ GP) or LCMV-NP aa1-558 (vv/NP). Virus was plaque-purified three times on Vero cells and virus stock was prepared by a single passage on BHK-21 cells. Stocks of recombinant vaccinia viruses were prepared by infection of $143 \mathrm{TK}^{-}$cells in media containing bromodeoxyuridine $(30,31)$.

$R N A$ analysis. RNA was extracted from tissues using the guanidinium isothiocyanate method. PCR for detection of LCMV-GP or -NP RNA was performed as described $(9,29)$.

Analysis of blood glucose and pancreatic insulin levels. Blood samples were obtained from the retroorbital plexus of mice and the amount of glucose was determined using ACCUCHECK II (Boehringer Mannheim, Indianapolis, IN). Insulin concentration in the pancreas was quantitated by radioimmune assay $(8,9)$. Diabetes was defined by blood glucose levels $>350 \mathrm{mg} / \mathrm{dl}$ in two consecutive measurements.

Oral administration of insulin. Mice were held firmly by gently gripping their fur over the neck with thumb and index finger and restraining the tail with the little finger. A volume of $0.5 \mathrm{ml}$ of a $2 \mathrm{mg} / \mathrm{ml}$ aqueous insulin solution was administered with a syringe through a blunt-ended curved feeding tube, which was inserted into the esophagus. Control groups received $0.5 \mathrm{ml}$ of saline solution or $2 \mathrm{mg} / \mathrm{ml} \mathrm{solu-}$ tions of BSA.

\section{Immunologic assays}

CTL and antibody assays. CTL activity was measured in a 5-6-h in vitro ${ }^{51} \mathrm{Cr}$ release assay $(8,9,30,31)$. Briefly, to judge CTL recognition and lysis, syngeneic or allogeneic target cells were either infected with LCMV ARM (MOI 1), or with recombinant vaccinia virus expressing the full-length LCMV ARM GP or NP (MOI 3). Uninfected target cells coated with LCMV peptides GP aa 33-41, 276-286, or NP 396-404, or NP aa 118-127 were also used as targets (29-31). Epitopes GP aa33-41, GP aa276-286, and NP aa396-404 of LCMV are all H-2 $\left(\mathrm{D}^{\mathrm{b}}\right)$ restricted for CTL recognition, while NP aa118-127 is restricted by the $L^{d}$ haplotype. Assays used splenic lymphocytes at effector to target ratios of 50:1, 25:1, and 12.5:1, or CTL clones and secondary CTL lines at ratios of 5:1, 2.5:1, and 1:1.

To determine CTL activity after secondary stimulation, spleen cells harvested from mice 30-120 d after primary intraperitoneal in- oculation with $1 \times 10^{5}$ pfu LCMV were incubated with MHCmatched, irradiated, LCMV-infected macrophages in the presence of $\mathrm{T}$ cell growth factor (Con A-stimulated rat spleen supernatant) and irradiated syngeneic spleen feeder cells $(8,9)$ for $5 \mathrm{~d}$. Medium used was $10 \%$ RPMI containing syngeneic, irradiated splenic feeder, and antigen-presenting cells $($ APC $)\left(5 \times 10^{5} /\right.$ well $)$. Medium was changed twice per week, TCGF (supernatant from ConA-stimulated rat splenocytes) was added as described (9). To stimulate insulin-reactive cells, insulin was added at a final concentration of $10-100 \mu \mathrm{g} / \mathrm{ml}$.

CTL precursor frequency was measured as described (9). Briefly, splenic lymphocytes were harvested $7 \mathrm{~d}$ after LCMV inoculation, diluted severalfold, and cultured for $6 \mathrm{~d}$ in 96-well flat-bottom plates with $\mathrm{T}$ cell growth factor and irradiated syngeneic LCMV-infected feeder cells.

Recovery of pancreatic lymphocytes. Lymphocytes were isolated from the pancreas as described (8). Briefly, tissues obtained from tg mice were freed from fat and surrounding lymphoid tissue. After collagenase digestion, lymphoid cells were purified through a Ficoll-Hypaque gradient. Thereafter, cells were either directly used in ELISPOT assays or additional purification was achieved by plating cells for $3 \mathrm{~h}$ at $37^{\circ} \mathrm{C}$ in flat plastic dishes in $10 \%$ RPMI. This led to adherence of monocyte/macrophage type cells. Lymphocytes did not adhere during this time span and were recovered by washing the dishes gently with medium. In other experiments, lymphocytes were stimulated for $2 \mathrm{~d}$ in 96-well plates coated with $\alpha \mathrm{CD} 3$ antibody at $1.0 \mu \mathrm{g} / \mathrm{ml}$ (hybridoma 145 2C11; Pharmingen, San Diego, CA).

Phenotyping, sorting, and selective depletion of lymphocytes. Cultured lymphocytes were phenotyped by FACS ${ }^{\circledR}$ analysis using monoclonal antibodies to murine CD4 (rat monoclonal antibody YTS 191.1.1) and CD8 (rat monoclonal antibody YTS 169.4.2) (9). For depletion of $\mathrm{CD}^{+}$or $\mathrm{CD}^{+} \mathrm{T}$ lymphocyte subsets, monoclonal rat antimouse antibodies 53-6-72 and GK 1.5 were used, respectively. Briefly, mice were injected intravenously with $1 \mathrm{mg} / 0.2 \mathrm{ml}$ of the appropriate antibody $2 \mathrm{~d}$ before and $4 \mathrm{~d}$ after LCMV infection. Depletion was confirmed by FACS ${ }^{\circledR}$ analysis $7 \mathrm{~d}$ after LCMV infection.

Assessment of cytokine production by single lymphoid cells (ELISPOT). Cytokines (IL-4, IL-6, IL-10, IL-2, TGF- $\beta$ and $\gamma$-IFN) produced by lymphocytes infiltrating the pancreas or by lymphocytes in the spleen were detected using the ELISPOT (Pharmingen) assay. All antibodies were from Pharmingen, except for rat anti-mouse TGF- $\beta$ (Serotec Ltd., Oxford, United Kingdom). Briefly, 96-well Millititer ${ }^{\mathrm{TM}}$ HA plates (Millipore, Bedford, MA) were coated with capture antibodies for IL-2, IL-4, IL-6, IL-10, TGF- $\beta$ and $\gamma$-IFN diluted 1:200. After incubation overnight at $4^{\circ} \mathrm{C}$, plates were washed four times with PBS, preincubated with RPMI containing 10\% FCS for $1 \mathrm{~h}$ at $37^{\circ} \mathrm{C}$, and then suspensions of lymphocytes recovered from the pancreas or spleen were added at various dilutions ranging from $1 \times$ $10^{4}$ to $1 \times 10^{2}$ cells $/$ well. The plates were incubated overnight at $37^{\circ} \mathrm{C}$ in a humidified incubator at $5 \% \mathrm{CO}_{2}$, washed three times initially with PBS, then an additional three times with PBS containing $0.05 \%$ Tween 20, and the respective detection antibodies for the cytokines were added at optimal dilution in PBS/Tween containing 1\% FCS. After overnight incubation at $4^{\circ} \mathrm{C}$, wells were washed three times in $\mathrm{PBS} /$ Tween and avidin-peroxidase conjugate (Boehringer, Indianapolis, IN) added at 1:500 dilution. After a 2-h incubation at room temperature, the color-substrate solution containing 3-amino-9-ethylcarbazole and $\mathrm{H}_{2} \mathrm{O}_{2}$ was added for $30 \mathrm{~min}$. Plates were rinsed in water and dried, and spots representing cytokine-producing cells were counted using an Olympus SZH stereo-zoom microscope. In some experiments, insulin was added at a final concentration of $10 \mu \mathrm{g} / \mathrm{ml}$ to the lymphocytes in the ELISPOT assay.

\section{Histology and immunocytochemistry}

Tissues taken for histologic analysis were fixed in zinc formalin (10\%) and stained with hematoxylin and eosin. Immunochemical studies were carried out on 6-10- $\mu \mathrm{m}$ freshly frozen cryomicrotome sections $(9,28)$. This allowed immunostaining of islets for expression of MHC class I and II, insulin, CD4, CD8, B220, F4/80, IL-4, and $\gamma$-IFN (Pharmingen). 


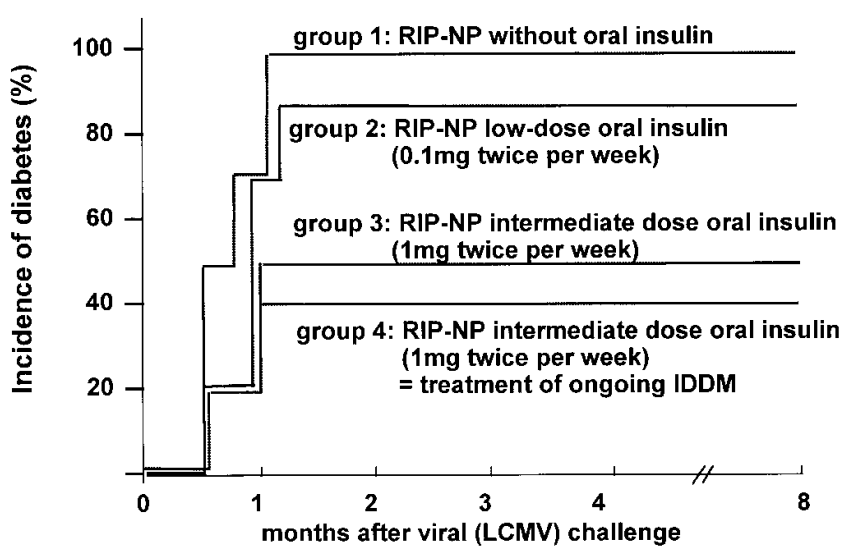

Figure 1. Oral administration of insulin prevents virus-induced IDDM. Each group consisted of 14-15 mice. Insulin was administered orally (see Methods) and blood glucose was measured at 1-wk intervals after each mouse received $1 \times 10^{5}$ pfu LCMV intraperitoneally. Four different groups are displayed in the figure. The first did not receive oral insulin but $0.5 \mathrm{ml}$ PBS instead. The second received a low-dose of oral insulin $(0.1 \mathrm{mg} / 0.5 \mathrm{ml})$ and treatment was begun 1 wk before LCMV infection. The third group received a higher dose of oral insulin $(1.0 \mathrm{mg} / 0.5 \mathrm{ml})$ similar to the mice in group 2 (before LCMV infection). The fourth group received $1 \mathrm{mg}$ insulin in $0.5 \mathrm{ml}$ orally, beginning $10 \mathrm{~d}$ after LCMV infection. All treatments were given twice a week for $4 \mathrm{wk}$ and then once per week for an additional 4 wk. Similar data were obtained in a repeated experiment. Diabetes is defined as development of blood glucose values exceeding $350 \mathrm{mg} /$ $\mathrm{dl}$ and mononuclear infiltration into the islets with destruction of $\beta$ cells $(8,9)$.

\section{Results}

Oral treatment with insulin prevents ongoing virus-induced slow-onset IDDM. RIP-NP tg mice were given different doses of insulin as displayed in Fig. 1. Treatment with $1.0 \mathrm{mg}$ of insulin twice a week reduced the incidence of virus-induced IDDM by more than $50 \%$. By contrast, administration of $0.1 \mathrm{mg}$ of insulin or saline did not prevent diabetes. Insulin therapy was effective either when given before initiating LCMV infection or when begun $10 \mathrm{~d}$ after LCMV infection, when $\mathrm{T}$ cell infiltration and islet destruction had already begun (9). Further, tg mice given insulin that did not develop IDDM during the 2-mo treatment phase did not develop diabetes over the next 8-mo observation period. By contrast, giving insulin orally had no protective effect on the rapid-onset IDDM model, in which diabetes develops 10-14 d after LCMV infection (data not shown).

Equivalent levels of low-affinity anti-self (viral) LCMV-specific CTL are found in spleens of tg mice with or without oral insulin treatment. Previously we documented the presence of lowaffinity, anti-self (LCMV-NP specific) CTL in RIP-NP H-2 $2^{\mathrm{d}} \mathrm{tg}$ mice after LCMV infection $(9,29)$. Table I shows that similar levels of CTL were found at 7 and $45 \mathrm{~d}$ after LCMV infection in either RIP-NP tg mice undergoing oral insulin therapy and not developing IDDM, in similarly treated mice that developed IDDM, or in non-insulin-treated mice that developed diabetes. All three groups of RIP-NP H-2 ${ }^{\mathrm{d}}$ tg mice generated LCMV-NPspecific CTL that were of significantly lower activity and affinity than CTL activity and affinity found in nontransgenic Balb/c H- $2^{\text {d }}$ controls. As documented elsewhere $(9,29)$ RIP-NP tg

Table I. Oral Insulin Treatment Does not Alter the Anti-self (LCMV-specific) Response of CTL Found in the Spleen, but Reduces the Anti-self (LCMV) Response of CTL Activities Found in the Islets of Langerhans

\begin{tabular}{|c|c|c|c|c|c|c|c|}
\hline & & & \multicolumn{4}{|c|}{ CTL response } & \multirow[b]{3}{*}{ IDDM } \\
\hline \multicolumn{3}{|c|}{ Experimental group } & \multicolumn{2}{|c|}{$\begin{array}{l}\text { Specific } \% \mathrm{Cr}^{51} \text { release } \\
\text { from } \mathrm{H}-2^{\mathrm{d}} \text { target cells }\end{array}$} & \multicolumn{2}{|c|}{ Affinity of CTL } & \\
\hline $\operatorname{Mice}\left(\mathrm{H}-2^{\mathrm{d}}\right)$ & Oral insulin & Day p.i. & ARM & vvNP & - log peptide & $\mathrm{C} 50(\alpha \mathrm{CD} 8)$ & \\
\hline Balc/c spl & No & 7 & $50 \pm 8$ & $42 \pm 7$ & 9 & $1.0 \mu \mathrm{M}$ & No \\
\hline RIP-NP $25-3 \mathrm{spl}$ & No & 7 & $18 \pm 8$ & $15 \pm 4$ & 7 & $0.1 \mu \mathrm{M}$ & No \\
\hline RIP-NP 25-3 spl & Yes & 7 & $22 \pm 7$ & $13 \pm 3$ & 7 & $0.1 \mu \mathrm{M}$ & No \\
\hline RIP-NP 25-3 spl & Yes & 45 & $35 \pm 5$ & $15 \pm 6$ & 7 & $0.1 \mu \mathrm{M}$ & No \\
\hline RIP-NP 25-3 spl & Yes & 45 & $22 \pm 3$ & $20 \pm 5$ & 7 & $0.1 \mu \mathrm{M}$ & Yes \\
\hline RIP-NP 25-3 spl & No & 45 & $38 \pm 5$ & $22 \pm 6$ & 7 & $0.1 \mu \mathrm{M}$ & Yes \\
\hline RIP-NP 25-3 pan* & Yes & 60 & $2 \pm 3$ & $9 \pm 4$ & ND & ND & No \\
\hline RIP-NP 25-3 pan* & Yes & 60 & $33 \pm 7$ & $17 \pm 2$ & ND & ND & Yes \\
\hline RIP-NP 25-3 pan* & No & 60 & $28 \pm 6$ & $19 \pm 6$ & ND & ND & Yes \\
\hline
\end{tabular}

Oral insulin treatment of RIP-NP H- ${ }^{\mathrm{d}} \operatorname{tg}$ mice does not reduce the systemic (splenic) anti-self (LCMV) specific CTL response, but reduces that response locally in islets of Langerhans. CTL assays were performed as described in Methods. Target cells were Balb/Clone7 (H-2 $2^{\mathrm{d}}$ ) fibroblasts uninfected or infected with LCMV (ARM), or infected with vaccinia viruses expressing the complete LCMV-NP ( $v v N P$ ). Background lysis of uninfected cells was $<5 \%$ in all assays and was subtracted from the lysis $\left({ }^{51} \mathrm{Cr}\right.$ release $)$ values shown. Five mice were tested per group and the mean $\pm 1 \mathrm{SE}$ is displayed. Primary CTL activity found in spleens $(s p l)$ was assessed on day 7 after LCMV infection and secondary CTL activity in spleens was determined on day 45 after infection after a 5-6-d in vitro stimulation in the presence of LCMV antigen and APC as described in Methods and reference 8. Affinities of anti-self CTL were recorded according to the minimal concentration of LCMV-NP peptide (RPQASGVYM) required for lysis of target cells by CTL. Note that high-affinity CTL found in nontransgenic mice require 2 logs less peptide for lysing target cells than low-affinity CTL found in $\operatorname{tg}$ mice (see also references 8 and 31). Further, low-affinity CTL required 10-fold less anti-CD8 antibody to inhibit CTL killing by $50 \%$ [C50 ( $\alpha$ CD8)] than high-affinity CTL from nontransgenic mice did. Statistical analysis demonstrated a highly significant difference between CTL activities found in the pancreas of insulin-treated mice that did not develop IDDM compared with CTL activities found in the pancreas of mice with IDDM $(P<0.009)$ and between CTL activities found in the spleen of all NP tg mice with low-affinity CTL compared with high-affinity CTL activities detected in nontransgenic Balb/c spleens $(P<0.02)$. *CTL found in islets of Langerhans (pan) were stimulated in vitro for $5 \mathrm{~d}$ in the presence of syngeneic irradiated APCs expressing LCMV antigens or peptide (RPQASGVYM) and feeder cells (see Methods). ND, not determined. 
mice delete high-affinity LCMV-NP-specific CTL through negative selection due to expression of LCMV-NP in the thymus.

Next, lymphocytes were isolated from the pancreas of tg mice. LCMV (anti-self) specific CTL were only detectable in $\operatorname{tg}$ mice that developed IDDM with or without insulin treatment. By contrast, LCMV (anti-self) specific CTL activity was not found in lymphocytes recovered from the pancreas of tg mice that received oral insulin and did not develop IDDM. Lymphocytic infiltrates were found in the islets of both groups of mice (Fig. 2) and oral insulin treatment did not affect the systemic (splenic) activity of anti-self (viral) specific CTL, but significantly reduced the activity of those anti-self CTL infiltrating the islets.

Oral insulin treatment reduces lymphocyte infiltration and aborts the upregulation of MHC class I and II molecules and $\beta$ cell destruction in the islets of RIP-NP tg mice. Histopathologic studies showed that LCMV-injected tg mice receiving oral insulin therapy and not developing IDDM had reduced lymphocyte infiltration and less $\beta$ cell destruction in their islets. In contrast, $\mathrm{tg}$ mice that were given a similar injection of LCMV but did

\section{oral insulin no IDDM}
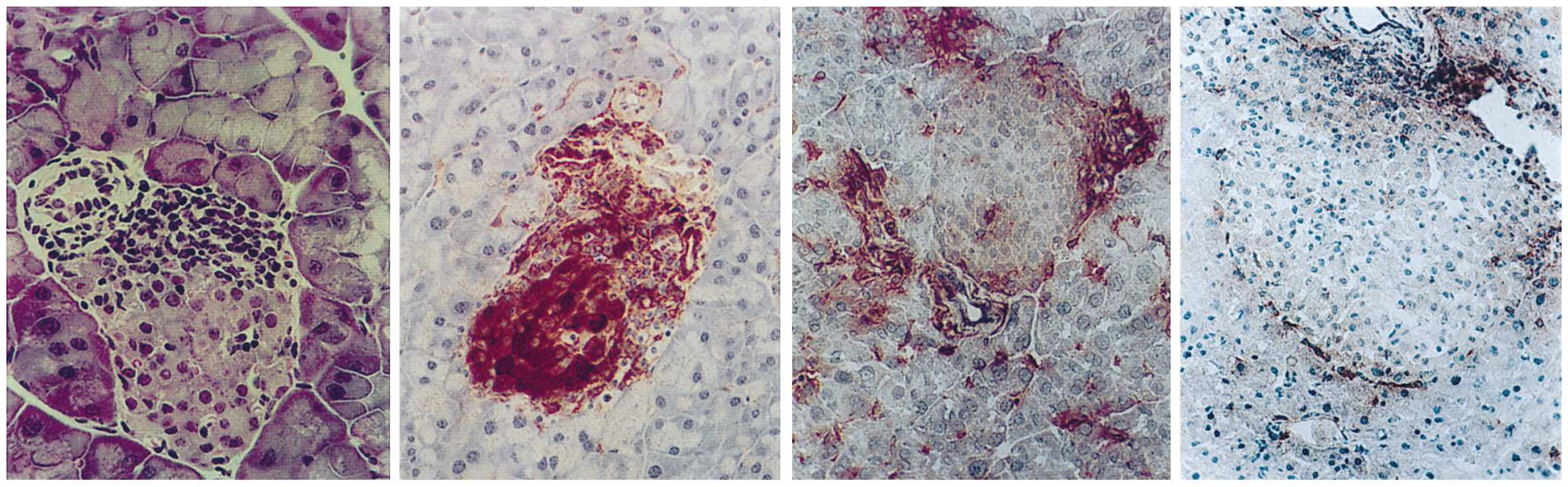

A

B

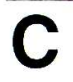

D

\section{no}

\section{oral insulin IDDM}
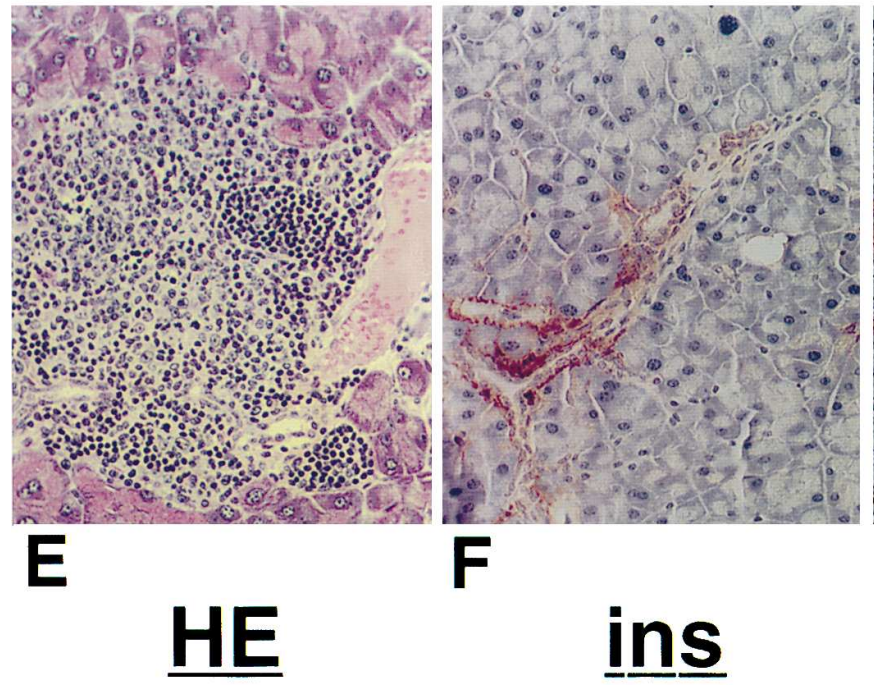

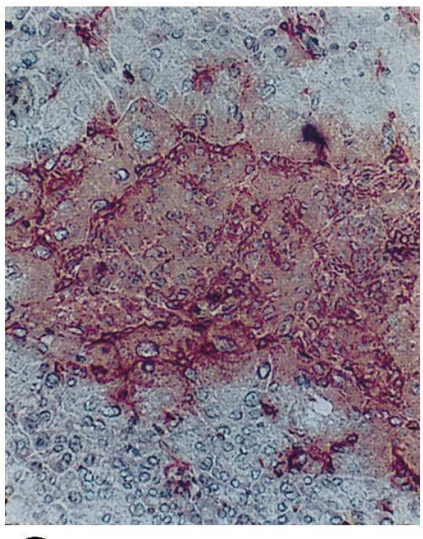

G

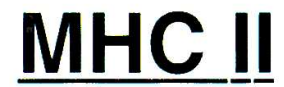

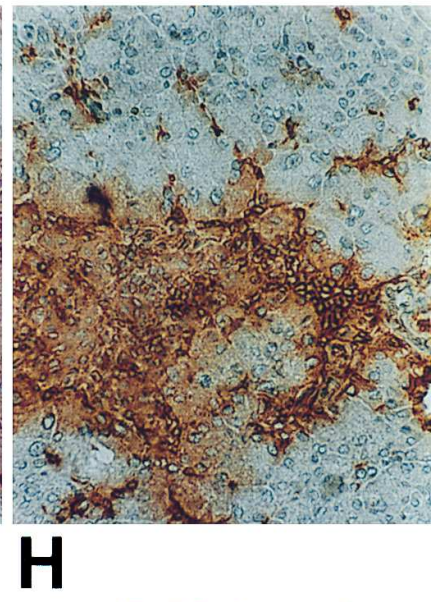

MHC I

Figure 2. Photomicrographs of histological sections obtained from islets of RIP-NP tg mice receiving oral insulin indicate that such mice have less T cell infiltration and less MHC class I and II expression than similar sections obtained from tg mice not receiving oral insulin. $A-D$ show pancreatic sections from tg mice that received oral insulin and did not develop IDDM 2 mo after infection with $1 \times 10^{5}$ pfu LCMV intraperitoneally. $E-H$ show sections from virus-infected tg mice that developed IDDM and did not receive oral insulin. Sections from tg mice receiving oral insulin and developing IDDM were identical to those shown in $E-H$ and are not displayed. Hematoxylin and eosin $(H E)$ staining and immunohistological staining for MHC class I and II molecules and for insulin were carried out as described (28). $A$ and $E$ compare lymphocyte infiltration into or around islets, $B$ and $F$ relative levels of insulin produced by $\beta$ cells, $C$ and $G$ expression of MHC class II molecules, and $D$ and $H$ expression of MHC class I molecules (see Methods). 
not receive oral insulin developed marked lymphocytic infiltration and $\beta$ cell destruction (Fig. $2, A$ and $B$ vs. $E$ and $F$ ). Upregulation of $\mathrm{MHC}$ class I and II molecules in islets was routinely observed after LCMV challenge in RIP-NP tg mice not receiving insulin (Fig. 2, $G$ and $H$, and reference 24 ). However, MHC class I and II levels were markedly reduced in tg mice receiving oral insulin and not developing IDDM (Fig. 2, $C$ and $D)$. Thus, despite the presence of a specific autoimmune response (anti-self [viral] T cells) and infiltration of lymphocytes into the target tissue (pancreatic islets), oral insulin treatment limited the upregulation of MHC class I and II molecules, diminished anti-self (viral) CTL activity in the islets, reduced $\beta$ cell destruction, and prevented IDDM.

The number of lymphocytes producing IL-4, IL-10, and TGF- $\beta$ is significantly increased in pancreatic infiltrates of $\mathrm{tg}$ mice receiving oral insulin and not developing IDDM when compared with non-insulin-treated littermates that developed IDDM. Cells infiltrating the islets of Langerhans were isolated 2 mo after LCMV infection. As seen in Fig. $3 A$, two- to threefold more cells produced IL-4, IL-10, and TGF- $\beta$ in the pancreas of $\mathrm{tg}$ mice given oral insulin but not developing IDDM when compared with tg mice that developed IDDM. The numbers of cells producing IL-2 (not shown) or $\gamma$-IFN (Fig. 3) were similar in the two groups. These results were confirmed in four independent experiments. Fig. $3 B$ shows an additional experiment in which purified, $\alpha \mathrm{CD} 3$-stimulated $\mathrm{T}$ lymphocytes from the pancreas were used and similar cytokine profiles were found comparing pancreata from insulin-treated mice with those from nontreated mice. Additionally, significantly less lymphocytes producing $\gamma$-IFN were found in the pancreas of oral insulin-treated mice without IDDM in this set of experiments using purified lymphocytes. Thus, the cyto- kines shown are predominantly produced by $\mathrm{T}$ lymphocytes infiltrating the pancreas rather than by monocytes or macrophages. At the same time a fraction of the infiltrating lymphocytes was grown in the presence of LCMV H-2 ${ }^{\mathrm{d}}$ peptide (see Methods). Confirming the results displayed in Table I, we were unable to detect LCMV-specific proliferation or CTL activity in cultures derived from oral insulin-treated mice without IDDM. In contrast, LCMV-specific proliferation and CTL activity was detected in cultures from mice that did not receive insulin and had IDDM.

Concurrently, we studied splenic lymphocytes from both groups of mice. In contrast to the cytokine profiles observed with lymphocytes harvested from the pancreas, spleens from both groups had equivalent numbers of $\gamma$-IFN, IL-4, IL-10, or TGF- $\beta$ producing lymphocytes. These results indicated that the accumulation of $\mathrm{Th}_{2}$ phenotype lymphocytes was a local phenomenon occurring within the islets of Langerhans. When nontransgenic mice were given oral insulin, no infiltrating lymphocytes were observed in their islets. The cytokine secretion profile of lymphocytes within their spleens was similar to that of spleens from $\mathrm{tg}$ mice that did or did not receive oral insulin (data not shown).

Production of IL-4 and IL-10 by pancreatic lymphocytes from tg mice given oral insulin but not developing IDDM can be enhanced in vitro by addition of insulin. This series of experiments determined whether insulin added directly to lymphocytes obtained from islets could enhance their production of IL-4 and IL-10. To perform these studies, insulin was added directly to lymphocytes in the cytokine (ELISPOT) assays or to in vitro cultures of lymphocytes that contained syngeneic APC. As seen in Fig. 4, addition of insulin enhanced the secretion of IL-4 and IL-10 by lymphocytes of $t g$ mice that received oral insulin

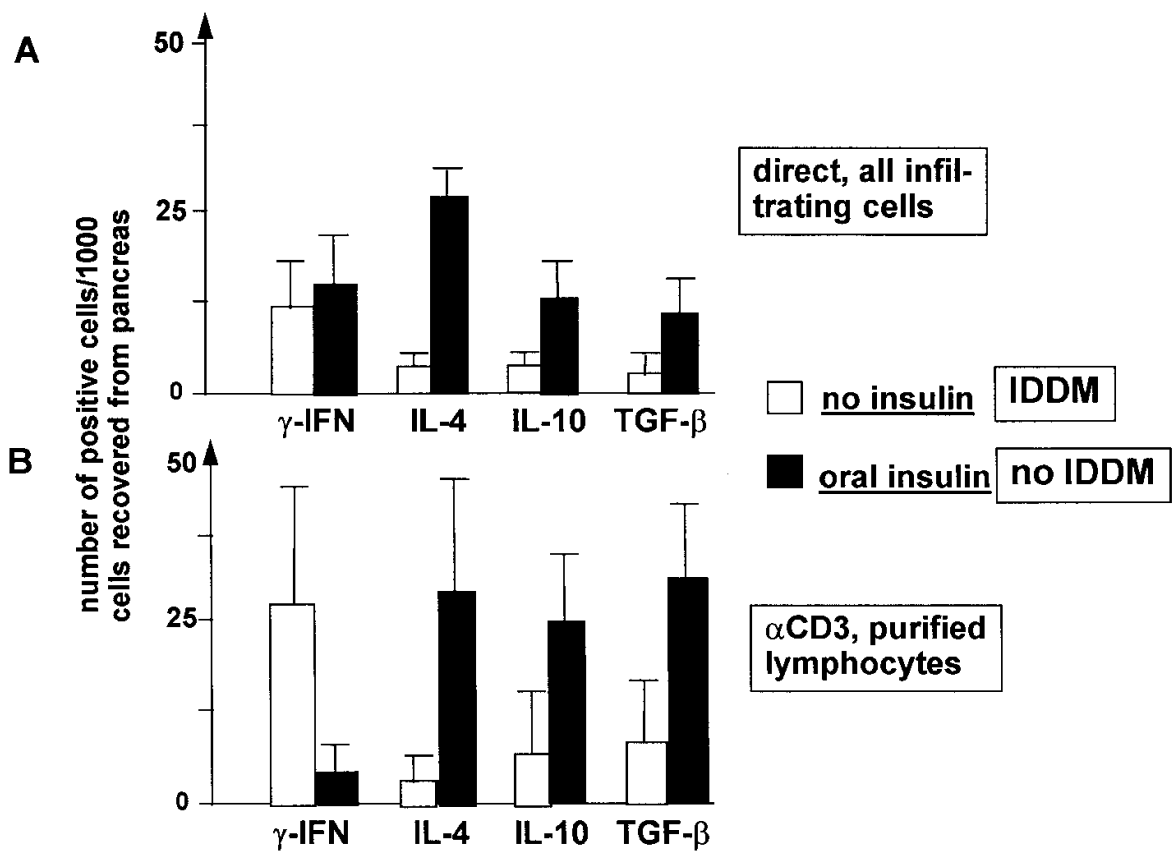

Figure 3. A greater number of lymphocytes obtained from pancreas of insulin-treated mice that did not develop IDDM produce IL-4, IL-10, and TGF- $\beta$ than lymphocytes obtained from pancreas of non-insulintreated mice with IDDM. Cytokine-producing lymphocytes were isolated from pancreas of RIP-NP tg mice with and without IDDM 2 mo after LCMV infection. Cells were then (without further manipulation) tested in ELISPOT assays. Four mice from each group were analyzed, with the mean \pm 1 SE being displayed. $A$ shows cytokine-producing cells isolated from the pancreas of insulin- or non-insulin-treated mice. APC, i.e., monocyte/macrophage type cells, were not removed. Note that no differences were found between the two groups in the numbers of lymphocytes that made $\gamma$-IFN. $B$ shows results obtained with the same experimental design, but using purified lymphocytes isolated from the pancreas (see Methods) stimulated for $2 \mathrm{~d}$ in the presence of $\alpha \mathrm{CD} 3$ antibody. Comparable differences between cells making IL-4,

IL-10, and TGF- $\beta$ from insulin (higher numbers) and non-insulin-treated (lower numbers) mice as those shown in $A$ were found. However, note that in this experiment there was a significantly higher number of $\gamma$-IFN-producing lymphocytes present in the pancreas of tg mice not receiving insulin and developing IDDM. Statistical analysis showed significant differences $(P<0.05)$ in all groups of cytokines measured comparing insulin-treated mice without IDDM with non-insulin-treated mice with IDDM. The only exception was the very similar levels of $\gamma$-IFN found in both groups of mice displayed in $A$. 

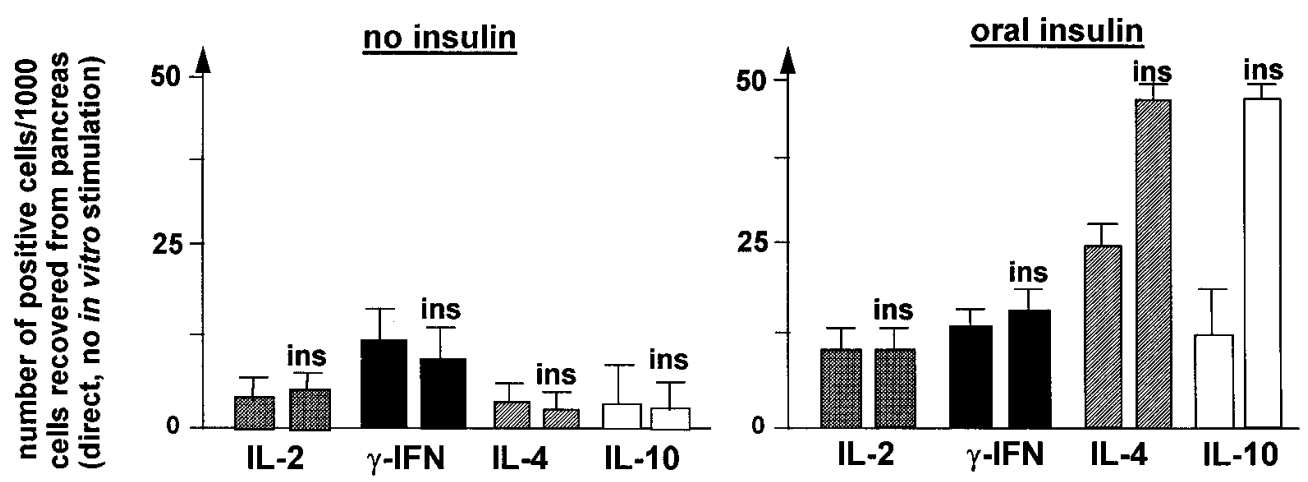

Figure 4. Production of IL-4 and IL-10 by lymphocytes isolated from RIP-NP tg mice with lymphocytic infiltration into the islets that received oral insulin treatment can be enhanced in vitro by addition of insulin. Cytokine assays on single cells (ELISPOT) were performed as described in Methods and the legend to Fig. 3. The figure shows numbers of lymphokineproducing cells that were directly isolated from RIP-NP tg

mice given oral insulin and not developing IDDM or from tg mice not given oral insulin and developing IDDM 2 mo after infection with $1 \times 10^{5}$ pfu LCMV. Cells (containing lymphocytes and macrophages/monocytes/dendritic cells) were added to the plates of the ELISPOT assay without in vitro manipulation and insulin was added directly to the assay at $10 \mu \mathrm{g} / \mathrm{ml}$ final concentration where indicated (ins). Four mice per group were analyzed, the mean $\pm 1 \mathrm{SE}$ is displayed. Statistical analysis showed significant differences $(P<0.05)$ in IL-4 and IL-10 production comparing numbers of cytokine producing cells recovered from oral insulin-treated mice tested in the presence of insulin with the same cell population tested in the absence of insulin (right).

treatment. In contrast, secretion of these cytokines by lymphocytes obtained from tg mice that developed IDDM with or without oral insulin therapy was not enhanced by the addition of insulin (Fig. 4). In additional studies, pancreatic lymphocytes were stimulated in vitro for $8 \mathrm{~d}$ and the numbers of lymphocytes producing IL- 2 and $\gamma$-IFN were enhanced in cultures derived from the pancreas of diabetic mice (data not shown), when compared with lymphocytes obtained from nondiabetic $\operatorname{tg}$ mice. These observations were made in four independent experiments.

\section{Discussion}

This study was undertaken to answer the following questions. First, is oral administration of one self-antigen effective against an autoimmune disease induced to a different specific self (viral)-antigen? Second, is oral tolerance therapy effective after the initiation of the autoimmune disease, when islet lesioning has already begun? Third, what is the effect of oral tolerance therapy on the anti-self (viral) immune response that ordinarily leads to IDDM? Using the RIP-LCMV model of virus-induced diabetes, we note that oral administration of a self-antigen (insulin) derived from the target organ can prevent autoimmune disease (IDDM) initiated by reactivity to a completely different (viral) self-antigen. Most important, the insulin treatment was effective after the autoimmune process had been initiated and islet injury had begun (reference 9, Fig. 1). The anti-self (viral) CTL response is aborted locally in the islets of Langerhans but not systemically in the spleen (Table I). Islets of tg mice that received oral insulin and did not develop IDDM contained larger numbers of T lymphocytes secreting IL-4, IL10 , and TGF- $\beta$ (Figs. 3 and 4), and showed downregulation of MHC class I and II expression (Fig. 2) and reduction of infiltrating lymphocytes.

Administration of a self protein (insulin) was effective both before and after the autoimmune response had been initiated by a specific viral trigger. In the latter case, insulin therapy was started after initial infiltration of $\mathrm{CD}^{+}, \mathrm{CD}^{+}$, and $\mathrm{B}$ lymphocytes into the islets began (9). These data have implications for the treatment of human type I diabetes with oral antigen administration, since prediabetic individuals that have antibodies to glutamic acid decarboxylase (GAD) $(6,7,32-34)$ and other islet cell antigens like the transmembrane tyrosine phosphatases IA-2 and IA-2 $\beta$ (35) as well as ongoing islet cell destruction could be treated according to our findings with the anticipation of preventing disease. We noted in repeated experiments that oral insulin therapy protected $>50 \%$ of RIPLCMV mice from developing IDDM. Interestingly, in the RIP-LCMV model, GAD-specific antibodies have been found before the onset of IDDM (Dyrberg, T., and M.B.A. Oldstone, unpublished observations).

Oral insulin treatment prevents virus-induced IDDM in the presence of an antigen-specific trigger without influencing the systemic (splenic) antiviral (self) immune response (Table I), responsible for initiating $\beta$ cell destruction (8). This indicates that regulatory cells act locally after specifically homing to the islets of Langerhans. All groups of mice, including those receiving oral insulin and not developing IDDM, show evidence of lymphocytic infiltration into the islets. However, mice treated with oral insulin show significantly less infiltration in their islets, no upregulation of MHC class I and II molecules, and a limited amount of $\beta$ cell destruction when compared with tg mice developing IDDM (Fig. 2). Further, in mice not developing IDDM as a result of the oral insulin therapy, the lymphocytes recovered from the islets fail to show anti-self (viral) CTL activity (Table I). In contrast, anti-self CTL is easily demonstrated by T lymphocytes recovered from islet lesions of $\mathrm{tg}$ mice that did not receive oral insulin treatment. It is not clear yet whether the lack of CTL activities in the islets of tg mice treated with oral insulin occurs because their anti-self CTL undergo apoptosis or are inhibited by local production of cytokines. However, we found that the local islet cytokine milieu of $\mathrm{tg}$ mice receiving oral insulin and not developing IDDM is skewed towards an increased production of IL-4, IL-10, and TGF- $\beta$, whereas mice with and without oral insulin treatment that developed IDDM have a cytokine milieu predominantly of $\gamma$-IFN (Fig. 3). These observations support the hypothesis that the prevention of IDDM by oral tolerance is via "bystander suppression" and is mediated by regulatory $\left(\mathrm{Th}_{2}\right) \mathrm{T}$ cells but not by selective deletion of insulin-reactive inflammatory cells. Studies in NOD mice, in which the initial autoantigens involved in IDDM are uncertain, have shown that administration of intermediate but not high dosages of oral antigen such as insulin $(36,37)$ and GAD protects against spontaneous 
diabetes. This effect is associated with $\mathrm{T}$ lymphocytes in the islets that predominantly secrete IL-4 and IL-10 and/or TGF- $\beta$ (37). It is believed that such cytokine-producing cells are activated in the gut after encountering orally administered antigen and/or peptide fragments presented by APC in the Peyer's patches or gut epithelium $(23,24)$. It is still controversial whether $\mathrm{CD}^{+}$or $\mathrm{CD}^{+}$lymphocytes alone or together are implicated in mediating bystander suppression $(23,24,38,39)$. Experiments to sort these possibilities out are under way.

Immune responses are regulated by a balance of $\mathrm{Th}_{1}(\gamma$-IFN) and $\mathrm{Th}_{2}$ (IL-4, TGF- $\beta$, IL-10) cytokines $(40,41)$. IL-4, IL-10, and TGF- $\beta$ inhibit $\mathrm{Th}_{1}$ cells in vitro and are thought to have an inhibitory effect on certain immune responses. The regulatory effect of several of these cytokines on the development of IDDM has been tested by engineering tg mice that express a cytokine under the RIP and crossing these mice to RIP-LCMV $\operatorname{tg}$ mice. With such double $\mathrm{tg}$ mice, we found enhancement of IDDM with $\gamma$-IFN (42) and IL-2 (28), but not with IL-4 or IL-10 (43). Others found that NOD mice expressing IL-4 in their $\beta$ cells do not develop IDDM (44). Extending these observations we found (45) that mice developing rapid onset IDDM have a predominance of $\gamma$-IFN while those with slow-onset IDDM before clinical manifestation of diabetes have an increase of IL-4, TGF- $\beta$, and IL-10 producing lymphocytes. Recently, we noted that disruption of the $\gamma$-IFN gene prevents IDDM in the RIP-LCMV tg model (von Herrath, M.G., and M.B.A. Oldstone, manuscript in preparation). Our findings reported here clearly indicate that a shift in the pancreatic cytokine profile from $\gamma$-IFN to IL-4, IL-10, and TGF- $\beta$ is associated with prevention of IDDM. Further, the main source for the production of these cytokines appears to be T lymphocytes, since depletion of monocytes/macrophages and purification of pancreatic lymphocytes with consecutive $\alpha \mathrm{CD} 3$ stimulation resulted in the same cytokine profiles that were obtained without purification (Fig. 3 B). Immunohistochemical analysis showed CD4 and CD8 lymphocytes in or around islets of insulin- or non-insulin-treated mice (data not shown) that are the potential source of the cytokines displayed in Figs. 3 and 4. It is important to note that $\mathrm{FACS}^{\circledR}$ analysis for intracellular cytokines produced by lymphocytes isolated from the pancreas is not possible because of the low numbers of cells that can be obtained per mouse (maximum $10^{4}$ lymphocytes). Our earlier studies have demonstrated that CD4 and CD8 lymphocytes can be amplified in vitro from islets $(8,45)$. For this study, however, in vitro amplification was avoided in order to not introduce artifacts into the cytokine analysis by skewing numbers of cytokineproducing cells.

Protection by oral insulin was effective in slightly more than $50 \%$ of treated tg mice. One reason for this partial protection may be that the number of regulatory cells induced by oral insulin is near the borderline of effectiveness. Thus, a combination therapy comprised of more than one orally administered self-antigen might enhance the production of regulatory cells and may prevent IDDM in all mice. Both the in vivo (Fig. 3) and in vitro (Fig. 4) models described here allow the testing of this hypothesis.

Oral insulin treatment is not effective in preventing the rapid onset diabetes occurring in RIP-GP tg mice. The reason is presumably that oral tolerance induction cannot prevent a rapid autoimmune process that solely depends on high-affinity CTL reacting only to one (viral) self-antigen. However, this therapeutic approach is effective in dampening a slowly pro- gressive autoimmune process (Fig. 1) similar to that occurring in humans developing IDDM, in which probably lower affinity $\mathrm{CD}^{+}$and $\mathrm{CD}^{+}{ }^{+} \mathrm{T}$ cells react against one or multiple self-antigens in a cascade-like effect (46-51). Thus, use of oral insulin or insulin-like analogues with a cocktail of potential self-antigens such as GAD, IA-2, etc., may provide an effective therapy for treating IDDM in humans. The RIP-LCMV model will be of enormous value in sorting out the role of these various potential self-antigens in the progression of IDDM.

\section{Acknowledgments}

This is publication No. 9424-NP from the Department of Neuropharmacology, Division of Virology, The Scripps Research Institute. This work was supported by National Institutes of Health grant AG04342 and by Diabetes Interdisciplinary Research Program grant DK49836 from the Juvenile Diabetes Foundation International (JDFI). M.G. von Herrath was supported by a fellowship from the JDFI and National Institutes of Health training grant AG00080.

\section{References}

1. Forster, D. 1985. Diabetes mellitus. In Harrison's Principles of Internal Medicine. 12th ed. 1739-1759.

2. Unger, R.H., and D.W. Foster. 1985. Diabetes mellitus. In Williams Textbook of Endocrinology. 7th ed. J.D. Wilson and D.W. Foster, editors. W.B. Saunders, Philadelphia. 1018-1080.

3. Eisenbarth, G.A. 1986. Type 1 diabetes mellitus. A chronic autoimmune disease. N. Engl. J. Med. 314:1360-1368.

4. Baekkeskov, S., and B. Hansen. 1990. Human diabetes. Curr. Top. Microbiol. Immunol. 164:1-193.

5. Atkinson, M.A., M.A. Bowman, L. Campbell, B.L. Darrow, D.L. Kaufman, and N.K. Maclaren. 1994. Cellular immunity to a determinant common to glutamade decarboxylase and Coxsackie virus in insulin-dependent diabetes. $J$. Clin. Invest. 94:2125-2129.

6. Hagopian, W.A., C.B. Sanjeevi, I. Kockum, M. Landin-Olsson, A.E. Karlsen, G. Sundkvist, G. Dahlquist, J. Palmer, and Å. Lernmark. 1995. Glutamate decarboxylase, insulin, and islet cell antibodies and HLA typing to detect diabetes in a general population-based study of Swedish children. J. Clin. Invest. 95:1505-1511.

7. Atkinson, M.A., D.L. Kaufman, D. Newman, A.J. Tobin, and N.K. Maclaren. 1993. Islet cell cytoplasmic autoantibody reactivity to glutamate decarboxylase in insulin-dependent diabetes. J. Clin. Invest. 91:350-356.

8. Oldstone, M.B.A., M. Nerenberg, P. Southern, J. Price, and H. Lewicki. 1991. Virus infection triggers insulin-dependent diabetes mellitus in a transgenic model: role of anti-self (virus) immune response. Cell. 65:319-331.

9. von Herrath, M., J. Dockter, and M.B.A. Oldstone. 1994. How virus induces a rapid or slow onset insulin-dependent diabetes mellitus in a transgenic model. Immunity. 1:231-242.

10. Bach, J.F. 1994. Insulin dependent diabetes mellitus as an autoimmune disease. Endocr. Rev. 15:516-542.

11. Tisch, R., and H. McDevitt. 1994. Antigen specific immunotherapy: is it a real possibility to combat T-cell mediated autoimmunity? Proc. Natl. Acad. Sci. USA. 91:437-438.

12. Feldmann, M., C. June, A. McMichael, R. Maini, E. Simpson, and J. Woody. 1994. T-cell targeted immunotherapy. Immunol. Today. 15:35-38.

13. Aichele, P., D. Kyburz, P.S. Ohashi, B. Odermatt, R.M. Zinkernagel, H. Hengartner, and H. Pircher. 1994. Peptide-induced T-cell tolerance to prevent autoimmune diabetes in a transgenic mouse model. Proc. Natl. Acad. Sci. USA. 91:444-448.

14. Lamont, A. 1994. Are we closer to selective immunotherapy for autoimmune diseases? Immunol. Today. 15:45-47.

15. Hancock, W., M. Polanski, J. Zhang, N. Blogg, and H. Weiner. 1995. Suppression of insulitis in NOD mice by oral insulin administration is associated with selective expression of IL-4, IL-10, TGF- $\beta$ and PGE. Am. J. Pathol. 117:1193-1199.

16. Bowman, M.A., E.H. Leiter, and M.A. Atkinson. 1994. Prevention of diabetes in the NOD mouse: implications for therapeutic intervention in human disease. Immunol. Today. 15:115-120.

17. Whitacre, C.C., I.E. Gienapp, C.G. Orosz, and D. Bitar. 1991. Oral tolerance in experimental autoimmune encephalomyelitis. III. Evidence for clonal anergy. J. Immunol. 147:2155-2163.

18. Trentham, D., R. Dynesius-Treutham, E. Orav, D. Combitchi, C. Lorenzo, K. Sewell, D. Hafler, and H.L. Weiner. 1993. Effects of oral collagen type II administration on RA. Science (Wash. DC). 261:1727-1736. 
19. Weiner, H.L., A. Friedman, A. Miller, S.J. Khoury, A. Al-Sabbagh, L. Santos, M. Sayegh, R.B. Nussenblatt, D.E. Trentham, and D.A. Hafler. 1994. Oral tolerance: immunologic mechanisms and treatment of animal and human organ-specific autoimmune diseases by oral administration of autoantigens. Ann. Rev. Immunol. 12:809-837.

20. Chen, Y., J. Inobe, R. Marks, P. Gonella, V. Kuchroo, and H. Weiner. 1995. Peripheral deletion of antigen-reactive T-cells in oral tolerance. Nature (Lond.). 376:177-180.

21. Chen, Y., V.K. Kuchroo, J.-I. Inobe, D.A. Hafler, and H.L. Weiner. 1994. Regulatory T cell clones induced by oral tolerance: suppression of autoimmune encephalomyelitis. Science (Wash. DC). 265:1237-1240.

22. Weiner, H., G.A. Mackin, M. Matsui, J. Orav, S. Khoury, D. Dawson, and D.A. Hafler. 1993. Double blind pilot trial of oral tolerization with myelin antigens in multiple sclerosis. Science (Wash. DC). 259:1321-1325.

23. Miller, A., O. Lider, A.B. Roberts, M. Sporn, and H.L. Weiner. 1992. Suppressor $\mathrm{T}$ cells generated by oral tolerization to myelin basic protein suppress both in vitro and in vivo immune responses by the release of TGF $\beta$ following antigen specific triggering. Proc. Natl. Acad. Sci. USA. 89:421-425.

24. Santos, L.M.B., A. Al-Sabbagh, A. Londono, and H.L. Weiner. 1993. Oral tolerance to myelin basic protein induces TGF $\beta$ secreting $\mathrm{T}$ cells in Peyer's patches. J. Immunol. 150:115a. (Abstr.)

25. Miller, A., O. Lider, A.B. Roberts, M. Sporn, and H.L. Weiner. 1992. Suppressor T cells generated by oral tolerance to myelin basic protein suppress both in vitro and in vivo immune responses by the release of TGF $\beta$ following antigen specific triggering. Proc. Natl. Acad. Sci. USA. 89:421-425.

26. Fontana, A., D.K. Sonstan, K. Frei, U. Malipiero, and H. Pfister. 1992. Modulation of the immune response by TGF $\beta$. Int. Arch. Allergy Immunol. 99: $1-7$.

27. Ohashi, P., S. Oehen, K. Buerki, H. Pircher, C. Ohashi, B. Odermatt, B. Malissen, R. Zinkernagel, and H. Hengartner. 1991. Ablation of tolerance and induction of diabetes by virus infection in viral antigen transgenic mice. Cell. 65 : 305-317.

28. von Herrath, M.G., J. Allison, J.F.A.P. Miller, and M.B.A. Oldstone. 1995. Focal expression of IL-2 does not break unresponsiveness to "self" (viral) antigen expressed in $\beta$ cells but enhances development of autoimmune disease (diabetes) after initiation of an anti-self immune response. J. Clin. Invest. 95: $477-485$

29. von Herrath, M.G., J. Dockter, M. Nerenberg, J.E. Gairin, and M.B.A. Oldstone. 1994. Thymic selection and adaptability of cytotoxic T lymphocyte responses in transgenic mice expressing a viral protein in the thymus. J. Exp. Med. 180:1901-1910.

30. Whitton, J.L., P.J. Southern, and M.B.A. Oldstone. 1988. Analyses of the cytotoxic T lymphocyte responses to glycoprotein and nucleoprotein components of lymphocytic choriomeningitis virus. Virology. 162:321-327.

31. Whitton, J.L., J.R. Gebhard, H. Lewicki, A. Tishon, and M.B.A. Oldstone. 1988. Molecular definition of a major cytotoxic T lymphocyte epitope in the glycoprotein of lymphocytic choriomeningitis virus. J. Virol. 62:687-695.

32. Petersen, J.S., T. Dyrberg, A.E. Karlsen, J. Mølvig, B. Michelsen, J. Nerup, T. Mandrup-Poulsen, and the Canadian-European Randomized Control Trial Group. 1994. Glutamic acid decarboxylase $\left(\mathrm{GAD}_{65}\right)$ autoantibodies in prediction of $\beta$-cell function and remission in recent-onset IDDM after cyclosporin treatment. Diabetes. 43:1291-1296.

33. Schatz, D., J. Krischer, G. Horne, W. Riley, R. Spillar, J. Silverstein, W. Winter, A. Muir, D. Derovanesian, S. Shah, et al. 1994. Islet cell antibodies predict insulin-dependent diabetes in United States school age children as powerfully as in unaffected relatives. J. Clin. Invest. 93:2403-2407.
34. Petersen, J.S., K.R. Hejnæs, A. Moody, A.E. Karlsen, M.O. Marshall, M. Høier-Madsen, E. Boel, B.K. Michelsen, and T. Dyrberg. 1994. Detection of $\mathrm{GAD}_{65}$ antibodies in diabetes and other autoimmune diseases using a simple radioligand assay. Diabetes. 43:459-467.

35. Van der Vegt, F.P., N.K. McLaren, C. Wasserfall, H. Xu, S. Lu, A. Notkins, and M. Lans. 1996. Autoantibodies in patients with IDDM to a transmembrane protein (IA-2) belonging to the tyrosine phosphatase family. J. Clin. Endocrinol. \& Metab. In press.

36. Weiner, H. 1995. Oral tolerance: mobilizing the gut. Hosp. Pract. 95:5357

37. Hancock, W., M. Polansli, J. Zhang, N. Blogg, and H. Weiner. 1995. Suppression of insulitis in NOD mice by oral insulin administration is associated with selective expression of IL-4, IL-10, TGF- $\beta$ and prostaglandin-E. Am. J. Pathol. 147:1193-1197.

38. Chen, Y., J. Inobe, and H. Weiner. 1995. Induction of oral tolerance to MBP in CD8 depleted mice. J. Immunol. 155:910-916.

39. Garside, P., M. Steel, F. Liew, and A. Mowat. 1995. CD4 but not CD8 cells are required for the induction of oral tolerance. Intern. Immunol. 7:501504

40. Katz, J.D., C. Benoist, and D. Mathis. 1995. T helper cell subsets in insulin-dependent diabetes. Science (Wash. DC). 268:1185-1188.

41. Liblau, R.S., S.M. Singer, and H.O. McDevitt. 1995. Th1 and Th2 CD4 ${ }^{+}$ $\mathrm{T}$ cells in the pathogenesis of organ-specific autoimmune diseases. Immunol. Today. 16:34-38.

42. Lee, M.-S., M. von Herrath, H. Reiser, M.B.A. Oldstone, and N. Sarvetnick. 1995. Sensitization to self antigens by in situ expression of interferon- $\gamma . J$. Clin. Invest. 95:486-492.

43. Lee, M.-S., L. Wogensen, J. Shirzuru, M.B.A. Oldstone, and N. Sarvetnick. 1994. Pancreatic islet production of murin interleukin-10 does not inhibit immune-mediated tissue destruction. J. Clin. Invest. 93:1332-1338.

44. Mueller, R., T. Krahl, and N. Sarvetnick. 1996. Pancreatic expression of IL-4 abrogates insulitis and diabetes in NOD mice. J. Exp. Med. In press.

45. von Herrath, M.G., S. Guerder, H. Lewicki, R. Flavell, and M.B.A. Oldstone. 1995. Coexpression of B7.1 and viral transgenes in pancreatic $\beta$-cells can lead to breaking of peripheral ignorance and spontaneous autoimmune diabetes. Immunity. 3:1-20.

46. Panina-Bordignon, P., R. Lang, P.M. van Endert, E. Benazzi, A.M. Felix, R.M. Pastore, G.A. Spinas, and F. Sinigaglia. 1995. Cytotoxic T cells specific for glutamic acid decarboxylase in autoimmune diabetes. J. Exp. Med. 181: 1923-1927.

47. Kaufman, D.L., M. Clare-Salzler, J. Tian, T. Forsthuber, G.S.P. Ting, P. Robinson, M.A. Atkinson, E.E. Sercarz, A.J. Tobin, and P.V. Lehmann. 1993 Spontaneous loss of T-cell tolerance to glutamic acid decarboxylase in murine insulin-dependent diabetes. Nature (Lond.). 366:69-72.

48. Tisch, R., X.-D. Yang, S.M. Singer, R.S. Liblau, L. Fugger, and H.O McDevitt. 1993. Immune response to glutamic acid decarboxylase correlates with insulitis in non-obese diabetic mice. Nature (Lond.). 366:72-75.

49. Cooke, A., and T. Mandell. 1994. Spontaneous loss of T-cell tolerance to glutamic acid decarboxylase in murine insulin-dependent diabetes. J. Endocrinol. Invest. 17:585-593.

50. Larger, E., C. Bécourt, J.F. Bach, and C. Boitard. 1995. Pancreatic islet $\beta$ cells drive $T$ cell immune responses in the nonobese diabetic mouse model. $J$. Exp. Med. 181:1635-1642.

51. Wegmann, D., R. Gill, M. Glaser, A. Schloot, and D. Daniel. 1995. Analysis of the spontaneous T-cell response to insulin in NOD mice. J. Autoimmun. 7:833-843. 